\title{
Jogpolitika
}

Hungler SÁra-Kende Ágnes*

\section{Nők a család- és foglalkoztatáspolitika keresztútján}

\author{
családpolitika - foglalkoztatáspolitika - munkajog - állásbiztonság - \\ családtámogatás - munka és magánélet egyensúlya
}

A család- és foglalkoztatáspolitika kapcsolata alapvetően meghatározza a nők munkaerőpiaci helyzetét. 2010 óta számos intézkedés született a gyermekvállalás ösztönzésének érdekében és a kisgyermekes nők foglalkoztatásának elősegítésére. Álláspontunk szerint a két szakpolitika célkitűzése nem áll egymással összhangban, amelynek eredményeképpen a nők munkaerőpiaci helyzete a férfiakéhoz képest lényegesen sérülékenyebb. Esettanulmányunkban azt vizsgáltuk, hogy az egyes szakpolitikai intézkedések és az ezek végrehajtására életbe léptetett jogszabályok miként hatnak a nők foglalkoztatottságára. Ehhez jogtudományi és szociológiai módszereket egyaránt használtunk. Az esettanulmány készítése során egyéni és csoportos interjúkat készítettünk különböző foglalkoztatási csoportokba tartozó kisgyermekes nőkkel és érdekvédelmi szervezeti képviselőkkel, amelynek eredményeit összevetettük a jogszabályok elemzésének eredményével. Interjú készült magas beosztásban dolgozó magas iskolai végzettségủ kisgyermekes anyával; csoportos interjú keretében egy borsodi falu roma kisgyerekes anyáival - akik közmunkásként dolgoztak az esettanulmány készítésének ideje alatt -, továbbá női civil szervezetek vezetőivel és a szakszervezeti föderáció női tagozatának vezetőjével is. Bár igyekeztük a minisztérium képviselöit is megszólítani a témánkkal kapcsolatban, ök végül nem adtak interjút nekünk. Véleményünk szerint a szakpolitikai célkitüzések közötti ellentét feloldása csak alapvető munkajogi reformokkal valósítható meg, elsősorban a munkaidő beosztására, a részmunkaidőre és a felmondási védelemre

* Dr. Hungler Sára, egyetemi adjunktus, ELTE Állam- és Jogtudományi Kar; tudományos munkatárs, MTA TK Jogtudományi Intézet, hungler.sara@tk.mta.hu, hunlger@ajk.elte.hu. Dr. Kende Ágnes, kutató, Central European University, Center for Policy Studies, kendea@ceu.edu. 
vonatkozó szabályok újragondolása szükséges, nemcsak az anyák, hanem a kisgyermekes apák védelmének szem előtt tartásával. Elemzésünk bemutatja továbbá, hogy a családpolitikai intézkedések elsősorban a magasabb jövedelmű családoknak kedveznek, ezért javaslatot tettünk az alanyi jogon járó juttatásokra vonatkozó szabályok újragondolására.

\section{Családpolitika és demográfiai kihívások}

A legtöbb európai ember munkájára önmaga kiteljesítésének egyik eszközeként tekint. Kutatási adatok alapján ez az egyik magyarázata annak, hogy miért maradnak a magasabb iskolai végzettséggel rendelkező nők sok esetben gyermektelenek. ${ }^{1}$ Ugyanakkor ez az összefüggés nem igazolt a férfiak esetében. Egyrészt azért, mert ők a gyermekvállalás okán nem maradnak ki a munkaerőpiacról, hisz a legtöbb országban ez még mindig az anyáktól követel meg időben nagyobb ráfordítást, a szülést követően ők maradnak otthon a gyerekükkel, ${ }^{2}$ amelynek következménye, hogy jövedelmük csökken, ráadásul gyakran a karrierjükben is törés következik be. ${ }^{3}$ Másrészt azért, mert a férfiak munkaerőpiaci értékét növeli a gyermekvállalás, mivel a család megnövekedett anyagi szükségletei miatt még elkötelezettebbek lesznek a munkájuk iránt és gyakran vállalnak pluszmunkát. Ezért - szemben az ugyanezen okok miatt „megbízhatatlan munkaerőnek” számító nőkkel, nő a munkaerőpiaci megbecsültségük.

Az OECD adatokból kiolvasható, hogy Magyarországon a kisgyermekes nők 2-3 év alatti gyerekkel nagyon alacsony arányban vannak jelen a munkaerőpiacon, míg ennél idősebb gyerek esetén a többi országhoz képest hasonló a nők munkaerőpiaci részvétele. Ennek okait egyrészt a szabályozási környezetben kell keresnünk, másrészt abban a tradicionális családfelfogásban, amit a mai politikai közbeszéd is erősen támogat. Például Dániában, ahol a legmagasabb a kisgyermekes nők foglalkoztatottsága, a kormány évek óta számos intézkedéssel igyekszik biztosítani a munkaerőpiac gender-semlegességét. A rövid, 18 hetes szülési szabadság, a kéthetes apáknak járó szabadság, illetve az apák és anyák részére is 32-32 hétben megállapított gyermekgondozási szabadság elősegíti a szülők közötti szerepek elosztását, és támogatja a nőket abban, hogy a szülés után hamar visszatérhessenek a munka világába. ${ }^{4}$ A sor végén elhelyezkedő Törökországban a nők alacsony munkaerőpiaci részvétele a nemi szerepek rendkívül tradicionális felfogásán túl gazdasági okokkal is magyarázható: a nők alacsonyabb iskolai végzettsége miatt a várható keresetük is lényegesen alacsonyabb, mint a férfiaké, így nem éri meg munkába állniuk, mert

${ }^{1}$ OECD Family Database. SF2.5. Childlessness, OECD, Paris. www.oecd.org/social/family/database (2019. 07. 15.).

2 BLAskó Zsuzsa: Nők és férfiak - keresőmunka, házimunka. KSH NKI Kutatási jelentések 2016, 82.; Életünk fordulópontjai, KSH NKI 2004-2005. http://demografia.hu/hu/tudastar/adatbazisok/22-adatbazisok/160eletunk-fordulopontjai (2019. 07. 15.).

${ }^{3}$ GILleSPIE, Rosemary: Childfree and Feminine: Understanding the Gender Identity of Voluntarily Childless Women. Gender and Society, 2003/1, 122-136. (https://doi.org/10.1177/0891243202238982).

${ }^{4}$ Andersen, Agnete: Women on the labour market in Denmark, The Ministry of Employment, Denmark, 2008. 
a család számára hasznosabb, ha a fizetetlen otthoni munkával és a gyermekek gondozásával foglalkoznak. ${ }^{5}$

A nők foglalkoztatási rátája (\%) (15-64 évesek körében a legfiatalabb (0-14 éves) gyerekük fényében.

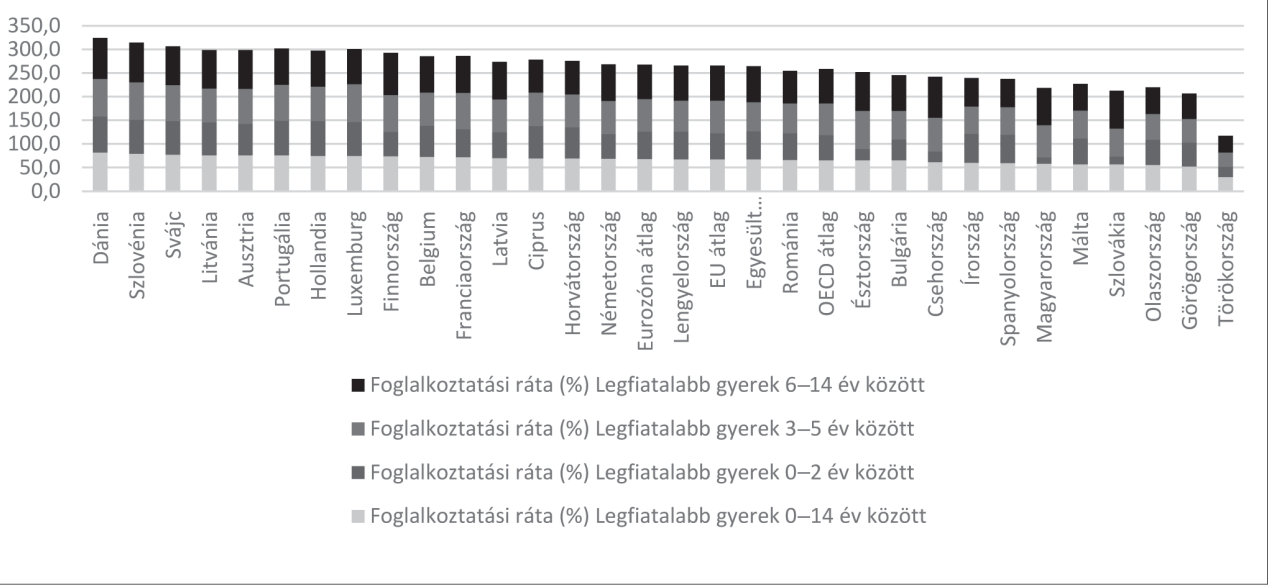

1. ábra. Az anyák munkaerőpiaci részvétele a legkisebb korú gyermekük fényében, 2014

Forrás: OECD Family Database ${ }^{6}$ saját szerkesztés

Ez a jelenség szorosan kapcsolódik a magyar családsegítő rendszer sajátosságaihoz, amelyek a hatvanas évekből származnak, amikor a GYES-t bevezették. Akkoriban a szocialista rendszer eröltetett iparosításával szemben, amely tömegesen szívta fel a női munkaerőt is, megjelent a kevesebb, de jobban képzett munkavállaló igénye. Mivel a rendszerben elképzelhetetlen volt a munkanélküliség, a GYES bevezetésével a nők egy részét ki lehetett vezetni a munkaerőpiacról. Ez a gazdasági cél sikeresen találkozott egyrészt a tradicionális családfelfogással, amely szerint a nők feladata elsősorban a család gondozása és ellátása, másrészt pszichológusok, gyermekorvosok és a gyerekekkel foglalkozó szakemberek egész sora erősítette a nőkben a családgondozói szerep prioritását, valamint az anya és a gyermek közötti korai kötődés nélkülözhetetlenségét. ${ }^{7}$ Egy korábbi, a kisgyermekes nők munkavállalási attitúdjét felmérő empirikus hazai kutatás eredménye egyértelműen rámutat, hogy a kisgyermekes anyák döntő többsége a három évre szóló otthonmaradást tart-

${ }^{5}$ KaraAlp-Orhan, Hacer Simay: What are the Trends in Women's Labour Force Participation in Turkey? European Journal of Sustainable Development, 2017/3, 303-312. (https://doi.org/10.14207/ejsd.2017.v6n3p303).

${ }^{6}$ http://www.oecd.org/els/family/LMF_1_2_Maternal_Employment.pdf (2019. 07. 15.).

${ }^{7}$ Ezekkel a kutatásokkal részletesen foglalkozik SzıkRA Dorottya: Eastern European Faces of Familialism: Hungarian and Polish Family Policies from a Historical Perspective. In: Ágota Scharle (szerk.): Manka goes to work. Public childcare in the Visegrad countries 1989-2009. Budapest Institute for Policy Analysis, Budapest, 2010, 83-96. 
ja optimálisnak a gyermek fejlődése szempontjából. ${ }^{8}$ A munka világába való visszatérés egy több szempontú racionális kalkuláció eredménye, melynek legföbb célja, hogy mind a gyermek, mind a család szempontjából megfelelő döntés szülessen. ${ }^{9}$

Ez a fajta gondolkodás, annak ellenére, hogy számtalan kutatási adat bizonyítja, hogy jó minőségủ kora gyermekkori intézmények semmilyen hátránnyal nem járnak a gyerekek számára, ${ }^{10}$ fiatal szülők egész generációinak gondolkodásmódját befolyásolták, ami aztán egyenesen vezetett akkor és azóta is az anyaság és a dolgozó nők szerepe közötti feloldhatatlan konfliktushoz. Ahogy az egyik fiatal anya az interjúban elmondta: „a nök maguk is fixáltak azzal kapcsolatban, de a férfiak még erösebben hisznek abban, hogy otthon kell maradniuk a nöknek a kisgyermekekkel, és nem ismerik fel annak a veszélyét, ha sok éven át nem dolgoznak. Ráadásul ez a férfiakat is kirekeszti a gyermekek életéböl". Az egyik szakszervezeti vezető szerint ez egy „közös játszma a férfiak és a nők között, mert a nők egy része vakációként tekint az otthon töltött három évre, amit a férfiak boldogan támogatnak". Szerinte a hátrányos helyzetű régiókban az anyaság „menekülési út” lehet a nők számára a munkanélküliségtöl, mivel ezt a három évet az állam biztosítja és fizeti a számukra. A szakszervezeti vezető szerint ez hamis biztonság, mivel a munkaerőpiacra való visszatérés lehetősége oly sok elmulasztott év után még nehezebb lesz. Ugyanakkor belátja, hogy van a nőkön egy erős pszichológiai teher is, hogy hát „az nem egy rendes anya, aki a picurka gyerekét beadja a bölcsibe. Most fontosabb, hogy elmegy és azt a 300000 Ft-ot megkeresi, és a szerencsétlen gyereket kirángatja reggel az ágyból? Ez még mindig benne van a társadalomban. Hogy nyíltan nem is vetjük meg, vagy nem is kövezzük meg, de hogy egyébként lenézzük ezért a nőket és ezért megszóljuk őket, az biztos.” Az egyik női civil szervezet vezetője a hosszú szülői szabadság mögött rejlő politikai ideológiát hibáztatja. Elmondása szerint „ez az egész azt sugallja, hogy a kötelességed otthon maradni, még fizetünk is és jogod van éhen halni a 28500 forintból". Az interjúk során az egyik civil szervezet vezetője kiemelte, hogy a „vállalati kultúrák kialakitása során sokkal jobban szem elött kellene tartani a nők igényeit", ám a legtöbb munkaadó nem tudja úgy alakítani a müködését, hogy a kisgyermekes anyák igényeinek megfeleljen, így úgy tünik, mintha a nők kevésbé lennének elkötelezettek a munkájuk iránt, mint a férfiak. Az interjúk során az egyik kisgyermekes anya azt mondta, hogy lehetetlen számára a nyolcórás munkát vállalni, mivel a bölcsőde, ahová járnak, legkésőbb délután öt órakor bezár. Hasonló tapasztalatai voltak egy vezető beosztásban dolgozó anyának is, aki csak jelentős anyagi ráfordítással tudja megoldani, hogy a bölcsőde merev nyitvatartása mellett a munkájának és a gyermeke igényeinek is meg tudjon felelni. „Egy egész hadsereget kell még az állami rendszer mellett üzemeltetni, hogy ezt kivitelezni tudjam."

${ }^{8}$ R. FEDOR Anita-Toldi Andrea: Labour market opportunities of women with young children after childbirth. Kontakt, 2017/3, 220-226.

${ }^{9}$ R. Fedor Anita: Egyensúlyban? - A munkaerő-piaci karriertől a familiarizmusig. Debreceni Egyetemi Kiadó, Debrecen, 2015, 252.

${ }^{10}$ Magnuson, Katherine A.-Ruhm, Christopher-Waldfogel, Jane: Does Prekindergarten Improve School Preparation and Performance? Economics of Education Review, 2007/26, 33-51.; SYLVA, Kathy et al.: The effective provision of pre-school education: Final Report of the EPPE project. Institute of Education, University of London, London, 2004. (https://doi.org/10.3386/w10452). 
Ezzel párhuzamosan a gyermekvállalás egyre költségesebb lesz, mivel jellemzően tovább tanulnak a gyerekek, így hosszabb ideig maradnak a szüleikkel, több támogatást igényelnek, míg az életformák pluralizálódása és a fokozott individualizáció miatt egyre kevésbé jellemző, hogy a gyerekek a családi gazdaság munkaerejét növelnék. Ennek fényében nem meglepő, hogy a népesség reprodukcióját biztosító helyettesítési ráta szinte egész Európában alacsony. ${ }^{11}$ Ugyanakkor feltételezhető, hogy Közép-Kelet-Európában más, a régióra jellemző sajátosságokkal is számolni kell, amelyek befolyásolják a gyermekvállalást, illetve az anyák foglalkoztatottságát. Elemzők szerint a posztszocialista társadalmakban az elmúlt 20-30 év során olyan jelentős strukturális és kulturális változások zajlottak le, amelyek a gyermekvállalás elhalasztásához vezettek. ${ }^{12}$ Régiós sajátosság, hogy az alacsony jövedelmi szint miatt szükséges, hogy mindkét szülő folytasson keresőtevékenységet, így ezekben az országokban nem jellemző, hogy a dolgozó nők nem vállalnak gyereket. A bizonytalan munkaerőpiaci helyzet csak Lengyelországban bizonyult gyermektelenséghez vezető tipikus életútelemnek, ${ }^{13}$ Csehországban az értékek változása, elsősorban az individualizáció és az önmegvalósítás kerültek előtérbe, illetve a szociális biztonság csökkenésével és a munkaerőpiaci kiszolgáltatottság növekedésével összefüggő bizonytalansági tényezők játszottak szerepet. ${ }^{14}$

A magyar gyermekvállalási hajlandóságot vizsgáló kutatások szerint a házasság és a gyermekvállalás szoros kapcsolatban van egymással, a gyermektelenek aránya lényegesen magasabb a nem házas nők, illetve az élettársi kapcsolatban élők körében, de az is megfigyelhető, hogy az élettársi kapcsolatok gyakran alakulnak házassággá, amikor a nő teherbe esik. ${ }^{15} \mathrm{~A}$ fiatalok gyermekvállalási aspirációi kedvező képet mutatnak, persze az nem garantálható, hogy az elképzelt gyermekszám realizálódni is fog. A korábbi kutatások eredményei alapján kijelenthetjük, hogy az első gyermekvállalás életkorának prognosztizálásában a korábban elindult trend folytatódása érhető tetten, mely szerint a nök a harmincas éveikhez közeledve kívánnak gyermeket vállalni. ${ }^{16}$

A magyar társadalom nem támogatja az egyedülállók gyermekvállalását. Azaz erős az a társadalmi norma, amely szerint egy gyereknek a legjobb, ha kétszülös családban nő fel, mivel ez ad számára megfelelő érzelmi és anyagi biztonságot. Ennek a

11 SzALMA Ivett-TAKÁCS Judit: A gyermektelenséget meghatározó tényezők Magyarországon. Demográfia, 2012/1, 44-68.

12 SPÉDER Zsolt-KAPITÁnY Balázs: Failure to realize fertility intentions: A key aspect of the post-communist fertility transition. Population Research and Policy Review, 2014/3, 393-418. (https://doi.org/10.1007/s11113-0139313-6).

${ }^{13}$ MYNARSKA, Monika et al.: Diverse paths into childlessness over the life course. ISID Working Papers $2013,34$. (https://doi.org/10.1016/j.alcr.2015.05.003).

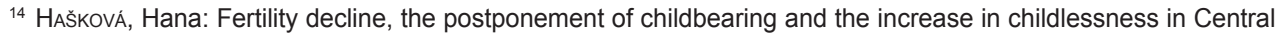
and Eastern Europe: A gender equality approach. In: Rosemary Crompton et al. (szerk): Women, men, work and family in Europe. Palgrave Macmillan, London, 2007, 76-85. (https://doi.org/10.1057/9780230800830_5).

15 KAPITÁnY Balázs-Spéder Zsolt: Gyermekvállalás. In: Monostori Judit-Őri Péter-S. Molnár Edit-Spéder Zsolt (szerk.): Demográfiai Portré 2009: Jelentés a magyar népesség helyzetéről. KSH Népességtudományi Kutatóintézet, Budapest, 29-41.

${ }^{16}$ R. FEDOR Anita: Családalapítás és gyermekvállalás a fiatalok körében. Acta Medicinae et Socilologica, 2016/7, 18. 
percepciónak a fennmaradását erősíti a nem megfelelő bölcsődei-óvodai ellátórendszer, illetve a munkaerőpiaci bizonytalanság is. ${ }^{17}$

Az 1980-as években a felnőtté válás markerei, azaz a munkába állás, a tartós párkapcsolat kialakítása, a szülőktől való különköltözés és a gyermekvállalás időben szorosan összefüggtek egymással, de a gyermekvállalás és a lakáshoz jutás ma is szoros kapcsolatban vannak egymással. ${ }^{18} \mathrm{~A}$ munkavégzés megkezdése is kihatással van a gyermekvállalásra, a dolgozó nőkre jobban jellemző, hogy későbbre halasztják az anyai szerepet. Ez feltehetően összefüggésben van azzal, hogy a munka nélküli nők számára egyrészt a karrierépítés nem jelent akadályt, másrészt a gyermekek után járó ellátások szolgálhatnak a jövedelem pótlására is.

Összefüggésben áll egymással az életkor és a gyermekvállalási hajlandóság is. A magyar társadalom a nők esetében átlagosan 39 évnél, a férfiak esetében 45,7 évnél húzza meg azt a határt, amely felett a gyermekvállalást nem támogatják, ugyanakkor a magasabb iskolai végzettséggel rendelkező nők gyakrabban halasztják a gyermekvállalást. ${ }^{19}$

Mindezeket figyelembe véve elmondható, hogy a 2019-ben életbe lépő családpolitikai eszközök célkitűzéseiket tekintve megfelelöen reflektálnak azokra a társadalmi jelenségekre, amelyek a gyermekvállalást ösztönzik. A Családvédelmi Akcióterv egyes elemei pont azokon a nehézségeken igyekeznek enyhíteni, amelyek a kutatások alapján a gyermekvállalás akadályát jelentik: ösztönzik a házasságkötést, segítik a saját lakás megszerzését és direkt transzferrel jutalmazzák a megszületett gyermekeket, miközben arra a korcsoportra koncentrálnak, akik esetében a legvalószínübb a gyermekvállalás.

További probléma lehet annak a kérdésnek a vizsgálata, hogy a jelenlegi szabályok mennyiben szelektívek, azaz minden társadalmi csoport számára elérhetök-e, vagy jellemzően a középosztálybeliekre szabott támogatási formákról beszélhetünk. Az egyes támogatási formák igénylési feltételeinek vizsgálata rámutat arra, hogy - hasonlóan a már meglévő családpolitikai eszközökhöz - a szegényebb rétegek számára nem elérhető az állami segítség a gyermekvállaláshoz.

Az intézkedéscsomag hatékonysága azonban nem önmagában vizsgálandó. Ahhoz, hogy több gyermek születhessen, elengedhetetlen, hogy a szülök olyan munkafeltételek szerint dolgozhassanak, amelyek állásbiztonságot és megfelelő rugalmasságot biztosítanak, lehetővé téve, hogy a munka és a magánélet egyensúlyba kerülhessen. Ezért a családpolitikai eszközök nem vizsgálhatók a foglalkoztatáspolitikai intézkedések nélkül.

\section{A családok támogatásának jogi eszközei}

A családpolitika sarkalatos törvénye a 2011. évi CCXI. törvény (Csvt.), amelynek célja, hogy elősegítse a családok belső stabilitását, szociális biztonságát; védje a

\footnotetext{
17 SzaLma Ivett-TAKÁCs Judit: Gyermektelenség - és ami mögötte van. Egy interjús vizsgálat eredményei. Demográfia, 2014/2-3, 109-136.

18 Szalma-TaKÁcs (2014): i. m., 120.

19 PAKSI Veronika-Szalma Ivett: Age norms of childbearing. Early, ideal and late childbearing in European countries. Review of Sociology, 2009/2, 57-80.
} 
családok autonómiáját; növelje a családok - föként a gyermeket nevelők - társadalmi megbecsülését; ösztönözze a gyermekvállalást; valamint erősítse a gyermekes családok kapcsolatát a munka világával. A kerettörvény átfogja a családok életét általában befolyásoló más jogágakat, mivel a klasszikus, szociális jogi eszközökön túl adókedvezmények révén szabályozza a családok életét. ${ }^{20} \mathrm{~A}$ családok védelmének egyik központi eszközével, a családtámogatásokkal kapcsolatban a Csvt. kimondja, hogy „a családok támogatása a szociális rászorultság alapján működtetett ellátórendszertől elkülönül”. Így a családtámogatások körébe alanyi jogon járó, fix összegű pénzbeli ellátások, valamint a biztosítotti jogviszony alapján járó támogatások tartoznak. ${ }^{21}$

A családtámogatásra való jogosultság biztosítási jogviszonyhoz való kötése azt eredményezi, hogy csak azok az anyák vehetik igénybe ezeket a - az alanyi jogon járó ellátásokhoz képest lényegesen magasabb összegü - támogatásokat, akik rendszeresen munkát végeznek, míg a munka nélküli vagy atipikus foglalkoztatási formákban dolgozó nők egyértelműen hátrányban vannak. Ez felerősíti a társadalomban végbemenő polarizációt, és az egyébként is jobb helyzetben lévő középosztályhoz tartozó családokat juttatja további előnyökhöz. ${ }^{22}$

Így például a gyermekgondozást segítő ellátás (GYES) demográns, azaz alanyi jogon jár és fix összegű támogatást jelent; ez a támogatás legfeljebb két gyerek után vehető igénybe és mértéke igen szerény, az öregségi nyugdíj legkisebb mértéke, amely nemcsak évek óta változatlan, de még nyugdíjjárulék is levonásra kerül belöle, így egy gyermek után nettó 25650 forintot kapnak kézhez azok az anyák, akiknek nincsen megfelelő biztosítási jogviszonyuk. Az ennél lényegesen magasabb összegű csecsemőgondozási díjra ${ }^{23}$ (CSED) azok az anyák jogosultak, akik a szülés előtti két évben legalább 365 napig biztosítottak voltak, és akiknek a gyermeke a biztosítás időtartama alatt, vagy ha az megszűnt, akkor az után negyvenkét napon belül született. Azaz a CSED összege annak megfelelöen alakul, hogy a jogosult megelőzően milyen összeget keresett és mennyi ideig volt biztosított. A CSED folyósításának lejártát követően igényelhető gyermekgondozási díj az egészségbiztosítás pénzbeli ellátásai keretében, a gyermekvállalás támogatására nyújtott pénzbeli ellátás. A gyermekgondozási díj nem szociális juttatás, biztosítási jogviszony, illetve felsőoktatási intézmény nappali tagozatán folytatott hallgatói jogviszony alapján megállapítható pénzbeli ellátás. A GYED havi összegének meghatározásakor ugyanúgy, mint a CSED esetében, a GYED-nél is a naptári napi alapot vagy naptári napi jövedelmet kell meghatározni. Tehát minél magasabb volt az anya korábbi jövedelme, annál nagyobb mértékü lesz az ellátás is, így az alacsony jövedelmű szülök hátrányt szenvednek.

${ }^{20}$ Ezenkívül a kapcsolati erőszak megelőzése érdekében egyes büntetőjogi és büntető-eljárásjogi eszközök is megjelennek a jogszabályban.

${ }^{21}$ Hoffmann István: Bevezetés a szociális jogba. ELTE Eötvös Kiadó, Budapest, 2015, 113.

22 SzIKRA Dorottya: Democracy and welfare in hard times: The social policy of the Orbán Government in Hungary between 2010 and 2014. Journal of European Social Policy, 2014/5, 486-500.

${ }^{23}$ A csecsemőgondozási díj összege a figyelembe vehető jövedelem alapján megállapított naptári napi alap 70\%-a. A CSED összegéből kizárólag személyijövedelemadó-előleget vonnak le, és érvényesíthető belőle a családi kedvezmény is. 
Ugyanakkor a GYES és a CSED is egyértelmüen az anyák otthonmaradását támogatja. A GYES-ben részesülő szülő a gyermek féléves koráig nem dolgozhat, nem folytathat keresőtevékenységet, a gyereket bölcsödében nem helyezheti el. ${ }^{24}$ A CSED esetében ez a célkitűzés még egyértelmübben megjelenik egyrészt azáltal, hogy a folyósítása alatt nem lehet munkát vállalni, így az anyáknak dönteniük kell, hogy élnek-e a Munka Törvénykönyve által biztosított lehetőséggel, és két hét szülési szabadság után visszatérnek dolgozni, vagy igénybe veszik az ellátást; ${ }^{25}$ másrészt azáltal, hogy az apák csak kivételes esetben jogosultak az ellátásra. ${ }^{26}$ Ezt támasztja alá az is, hogy a foglalkoztatási statisztikák szerint a három év alatti gyermekeket nevelő nők munkaerőpiaci jelenléte rendkívül alacsony. ${ }^{27}$

Hasonlóképpen a magasabb jövedelmű családoknak kedveznek leginkább az adókedvezmények nyújtotta lehetőségek is. A családi adókedvezmény a családosok jövedelmének összevont adóalapját, azaz az összes bruttó keresetet csökkentő kedvezmény, amelynek mértéke a gyermekek számától függ. Ha az adóköteles jövedelemből nem érvényesíthető teljes mértékben, akkor a járulékokból is levonható. A családi adókedvezményt az a szülő, nevelőszülő vagy gyám, illetve az ő házastársuk, élettársuk veheti igénybe, aki személyijövedelemadó-köteles jövedelemmel rendelkezik, és családi pótlékra jogosult. A kedvezmény a CSED-böl és a GYED-böl is levonható, viszont a GYES-böl (és a GYET-ből) nem érvényesíthető, mivel ezek adóköteles jövedelmek. ${ }^{28}$

A 2019-ben bejelentett Családvédelmi Akcióterv egy több pillérböl álló intézkedéscsomag, amely a születésszám növekedését hivatott segíteni többféle hitelfelvétellel, gépkocsivásárláshoz kapcsolódó állami támogatással, adókedvezménnyel, illetve a bölcsődei helyek számának növelésével. A programban felkínált támogatásokat - hasonlóan a korábban is meglévő családtámogatási rendszerhez - elsősorban a magasabb jövedelmű családok tudják maximálisan hasznosítani, illetve ennek a programnak is fontos eleme, hogy számos támogatási formát csak biztosítási jogviszonnyal rendelkezők tudnak igénybe venni. A „babaváró hitelt” azok a házaspárok vehetik igénybe, ahol a feleség 18 és 40 év közötti, és legalább egyikük 3 év biztosítási jogviszonnyal rendelkezik. A családi otthonteremtési kedvezmény (CSOK) jogosultsági feltételei között is szerepel a biztosítási jogviszony megléte, amely a gyermekek számával emelkedik.

${ }^{24}$ Ezt követően viszont időkorlátozás nélkül dolgozhat, és ezalatt a gyermeket családi napköziben vagy bölcsődében helyezheti el.

${ }^{25}$ Az Mt. 127. § (1) bekezdését a 2013. évi CCLII. törvény módosította a Bizottság ajánlására a szülési szabadság és a munkavállalás közötti sikeres átmenetet elősegítő szakpolitikai iránymutatás érdekében, így a magyar szabályozás összhangba került a (Módosított) Európai Szociális Karta rendelkezéseivel is.

${ }^{26} \mathrm{Az}$ apák abban az esetben jogosultak igénybe venni a CSED-et, ha a gyermeket szülö nő szülöi felügyeleti joga megszünt, illetve az örökbefogadó apa, ha a nő egészségi állapota miatt kikerül abból a háztartásból, ahol a gyermeket gondozzák, vagy meghal, valamint ha a férfi a csecsemőt egyedül vette örökbefogadási szándékkal nevelésbe.

${ }^{27}$ Magyarországon az egyéves kor alatti gyereket nevelő nők 86,45\%-a marad távol a munkaerőpiactól, míg a 0-2 éves gyerekeknek csupán a 14,46\%-a jár bölcsődébe; ez az arány az OECD-országokban átlagosan 36,1\%. OECD Family Database, 2013.

28 1995. évi CXVII törvény, 29/A és 29/B §. 
Sajátos magyar eleme a támogatási rendszernek, hogy a támogatások nincsenek felső jövedelmi határhoz kötve, így azokat akár a legtehetősebb családok is igénybe vehetik. Ez tovább erősíti, hogy a rendszer a közép- és felsőosztálybeli családok számára kedvez igazán, gyakorlatilag kézzelfogható anyagi támogatás nélkül hagyva a legszegényebb rétegeket. A rendszerből így kimaradnak azok az alacsony jövedelmü, munkanélküliséggel küzdő családok, akik szintén - vagy még inkább rászorulnak az állami segítségre. Ezáltal tovább élesedik a különbség a „rendes” és a „dologtalan” családok között, tovább erősítve az érdemtelen szegények társadalmi osztályokat elválasztó funkcióját. Ezáltal a „rendes” családok további megerősítéshez juthatnak abban, hogy ők megfelelnek a társadalom és az állam által felállított normáknak. ${ }^{29}$

Ezt támasztja alá az is, hogy a jövedelem szintjéhez, illetve a kellő biztosítási idő meglétéhez kötött támogatásokhoz képest az alanyi jogon járó családi pótlék öszszege nemcsak rendkívül alacsony, de 2008 óta változatlan. Jelenleg 12200 forint a legalacsonyabb, 25900 forint a legmagasabb folyósított összeg havonta. A folyósított összeg függ a gyermekek számától, attól, hogy egyedülálló-e a nevelő szülő, vagy teljes családban nevelkedik a gyermek, illetve egészséges vagy tartósan beteg gyermekről van szó. ${ }^{30}$ Ráadásul a 2010-es kormányváltás után a családi pótlékot - hasonlóan az 1998-at követő reformhoz - kettéválasztották, így az óvodáztatási kötelezettség 2015. szeptember 1-jei bevezetésével gyakorlatilag 3 éves kortól csak a köznevelésben való részvétel esetén biztosítható az ellátás. ${ }^{31}$

A családi pótlék feltételhez való kötése és a jogkövetkezmények szabályozása azt a szándékot tükrözi, hogy kiszürje a rendszerből azokat, akik kvázi nem megfelelően nevelik a gyermekeiket. Ugyanakkor a Családvédelmi Akcióterv keretében meghirdetett, ennél lényegesen magasabb összegű támogatások esetében érdektelen, hogy a támogatást milyen „minőségü” szülő veszi igénybe, járatja-e iskolábaóvodába a gyerekét, vagy egyébként a gyerekek jólétének biztosítására vagy fokozására használja-e a pénzt.

A gyermeknevelés anyagi terheinek csökkentése az alacsony jövedelmú családok esetében is indokolt lenne. Feltehetően nagyban hozzájárulna a szegénység csökkentéséhez az alanyi jogon járó juttatások közül a GYES és családi pótlék megemelése. Amennyiben a családtámogatástól valóban a fertilitás növekedését várjuk, úgy nem tűnik logikusnak, hogy a támogatások csak egy jól körülhatárolható rétegre céloznak. Ráadásul a GYES és a családi pótlék megemelése lényegesen több családot érne el, mint a lakás- vagy autóvásárlási kedvezmények. ${ }^{32}$

${ }^{29}$ GANS, Herbert J.: Mire szolgálnak az érdemtelen szegények? Esély, 1992/3. 3-17.

30 1998. évi LXXXIV. törvény 9. §.

${ }^{31}$ Hoffmann: i. m., 115-117.

32 A KSH adatai alapján 2017-ben 1,7 millió gyermek részesült családi pótlékban, GYES-t 160 ezren, GYED-et 97 ezren vettek igénybe. Az EMMI adatai szerint 2015 és 2018 között 90 ezer család igényelt CSOK-ot, amelynek mértéke 600000 forint és 10000000 forint között volt. A CSOK-igénylők száma a jövőben várhatóan csökkeni fog, mivel a szülőképes nők száma 2020 és 2040 között folyamatosan csökkeni fog. 2018-ban a családi pótlék 316,5 Mrd Ft-os előirányzata 99,3\%-ra, az anyasági támogatás 107,3\%-ra, a gyermekgondozást segítő ellátás 93,6\%-ra, a gyermeknevelési támogatás 88,9\%-ra teljesült. Ez összesen 1,9 millió támogatott között oszlott meg. Ezzel szemben 2018-ban a CSOK-ra előirányzott költségvetési támogatás 100 milliárd 


\section{A nők foglalkoztatását elösegítő jogi eszközök}

A Csvt. mint keretjogszabály rendelkezik a kiskorú gyermeket nevelő szülök kiemelt munkajogi védelméröl, illetve a szülői szerep és a munkavégzés összehangolásáról, valamint a családi élet védelmét biztosító kedvezményekről. Célkitǔzése szerint az állam a család és a munkavállalás összeegyeztethetőségének érdekében ösztönzi a részmunkaidőben történő, illetve az egyéb atipikus foglalkoztatási formákban való munkavégzést. ${ }^{33}$ A munka törvénykönyvéröl szóló 2012. évi I. törvény (továbbiakban: Mt.) valóban számos rendelkezést tartalmaz erre nézve, de kérdés, hogy tényleg hatékonyan védi-e a jogszabály a családos munkavállalókat.

Az 1992-es Munka Törvénykönyvét is joggal érte kritika, ám a jelenlegi kódex tovább csökkentette azt a kiszámíthatóságot, amely a szülöknek, a családfenntartóknak nélkülözhetetlen a kiegyensúlyozott családi élet megteremtéséhez. Ehhez a munkavállalói és a szülői szerep egymással egyensúlyba hozására lenne szükség, ám a hatályos szabályozás alapján a jó dolgozó nem lehet egyben jó gondozó is, és ennek - a családok mellett - a munkaviszony mindkét alanya kárát látja. Ez természetesen nemcsak Magyarországra igaz, ezt igazolja az EU 2019/1158. számú (2019. június 20.) irányelvének (továbbiakban: (EU) 2019/1158. irányelv) preambuluma is, amely kiemelten foglalkozik a gondozási feladatok és a munkavégzés összehangolásának problémájával. ${ }^{34}$ Öt évvel ezelött elmaradt az új törvénykönyv átfogó, családszemléletű kritikája, ezért továbbra is aktuális a joganyag felülvizsgálata, különösen a munka és magánélet közötti egyensúly megteremetését célzó új irányelvvel kapcsolatos jogharmonizációs kötelezettség kapcsán. A 2019. júliusában hatályba lépő új irányelv számos ponton hoz változást a szabályozásban annak érdekében, hogy a szülők és a gondozók vonatkozásában a munka és a magánélet közötti egyensúly megteremtődjön, ezáltal a munkavállaló szülök és gondozók a munkaerö-állományban maradjanak, és lehetővé váljon számukra, hogy munkarendjüket személyes igényeikhez és preferenciáikhoz igazítsák. ${ }^{35}$ Vizsgálatunkat a munkaidőre, a részmunkaidőre és a felmondási védelem szabályaira összpontosítjuk, és vizsgáljuk az apákra vonatkozó rendelkezéseket is.

forint volt, ebből nagyjából 31 ezer család kapott támogatást. Lásd TATAY Tibor-SÁGI Judit-LENTNER Csaba: A családi otthonteremtési kedvezmény költségvetési terheinek elöreszámítása, 2020-2040. Statisztikai Szemle, 2019/2, 200-202.; KSH 2.5.3. Családi pótlék, gyermekgondozást segítő ellátás és gyermekgondozási díj (1990-), Lakossági lakáshitelezés, 2018 KSH, Statisztikai Tükör, 2019. április 15.; KovÁcs Vera: A lakhatási célú költségvetési kiadások. Habitat for Humanity, 2018. Éves jelentés a lakhatási szegénységröl.

${ }^{33}$ 2011. évi CCXI. törvény 15. §.

${ }^{34}$ Az Európai Parlament és a Tanács (EU) 2019/1158 irányelve (2019. június 20.) a szülök és a gondozók vonatkozásában a munka és a magánélet közötti egyensúlyról és a 2010/18/EU tanácsi irányelv hatályon kívül helyezéséröl, L-188/79, 2019.7.12. lásd különösen a [6], [12] és [27]-[29] preambulum-bekezdéseket.

${ }^{35}$ Az Európai Parlament és a Tanács (EU) 2019/1158 irányelve (2019. június 20.) a szülők és a gondozók vonatkozásában a munka és a magánélet közötti egyensúlyról és a 2010/18/EU tanácsi irányelv hatályon kívül helyezéséröl, L-188/79, 2019.7.12. [10], [11] és [34] preambulum-bekezdés. 


\subsection{A munkaidő}

Az EU 2019/1158. irányelv egyik központi eleme a családos munkavállalók rugalmas munkaidő-beosztásának biztosítása. Az Mt. alapján a munkáltató a munkaidő beosztásának jogát - a munkavégzés önálló megszervezésére tekintettel a munkavállaló számára átengedheti. Az eredeti törvényszöveget ért EU-s bírálat szerint, ha a munkavállaló munkaidejének feléről a munkáltató rendelkezhet, akkor nem vonható ki a munkaidő hosszára és beosztására vonatkozó normák hatálya alól. Így az Mt. 96. § (2) bekezdése módosította a kötetlen munkarendre vonatkozó szabályozást, megszüntette a feles szabályt, azaz hogy a kötetlen munkarendben dolgozó munkavállalók legalább heti átlagban a napi munkaidejük fele tekintetében maguk rendelkeznek a munkaidejük felett. Az új szöveg alapján ugyanakkor a munkáltató továbbra is meghatározhat olyan feladatokat, amelyeket kizárólag meghatározott időpontban teljesíthet a munkavállaló - úgy, hogy a törvény ennek nem szab felső határt, ugyanakkor a munkavállaló elesik minden garanciális intézménytől a rendkívüli munkaidő, a napi, heti pihenőidő, a munkaszüneti napok tekintetében. Félő, hogy a jogalkotó csak formálisan kívánt megfelelni az uniós jognak, hiszen semmilyen felső határt nem szab abban a tekintetben, hogy milyen mértékü lehet az az idő, amellyel a munkáltató rendelkezik. Az is aggályos, hogy az átengedésről a munkáltató maga rendelkezik, garanciális elem lehetne, ha ilyen változtatás a felek közös megegyezésén alapulna, illetve a munkavállaló maga is kezdeményezhetné.

Ahhoz, hogy a családok minőségi időt tölthessenek együtt, fontos, hogy a hétvégéket, de legalább annak egy részét együtt tölthessék. 2016-ban megszúnt az a védelmi rendelkezés, amely szerint amennyiben készenléti jellegü munkakörben foglalkoztatott munkavállaló részére vasárnapra rendes munkaidőt osztottak be, úgy a megelőző szombatra rendes munkaidőre nem lehetett beosztani.$^{36} \mathrm{~A}$ védelem eltörlése még mennyiségi korlátot sem állít fel (azaz, maximum hány hétvégén megengedett, hogy a szombatot és vasárnapot is a munkahelyen tölti a munkavállaló). Az a szülö, aki sem szombaton, sem vasárnap nincsen a családjával, nyilvánvalóan nem tudja megfelelően ellátni a családi feladatait, ezenkívül adott esetben a gyerek teljes hétvégi felügyeletét meg kell szerveznie, akár költségek árán is.

\subsection{A részmunkaidő}

A kisgyermekes szülök, elsősorban a nők számára klasszikusan elképzelt atipikus munkavégzési forma a részmunkaidő, amely alkalmas arra, hogy segítse a kisgyermekes nők visszatérését a munka világába. Ezt az igényt igyekszik kiszolgálni az Mt., amikor biztosítja, hogy a munkáltató köteles az általános, teljes napi munkaidő felére, azaz napi négy óra tartamú részmunkaidőre módosítani a munkaszerződést.

Elvileg a magyar jogrendszer is lehetőséget ad arra, hogy a részmunkaidő mértékét a felek saját érdekeiknek megfelelően határozzák meg. Ugyanakkor ha mun-

${ }^{36}$ Az Mt. 101. § (3) bekezdését a 2016. évi LXVII. törvény 130. §-a helyezte hatályon kívül. 
kába visszatérni kívánó szülő nem a klasszikus négyórás részmunkaidőben kíván dolgozni, hanem például a napi hat óra felelne meg számára, akkor ezt a munkáltató már nem köteles figyelembe venni. ${ }^{37} \mathrm{Ez}$ is oka lehet annak, hogy hazánkban a részmunkaidöben foglalkoztatottak körében a nök száma és aránya is csökken, amellett, hogy az összes részmunkaidős munkavállaló száma is messze az uniós átlag alatt van. ${ }^{38}$

A munka és a magánélet megteremtéséhez elengedhetetlen lenne, hogy a jogalkotó nagyobb szabadságot adjon a gyermekgondozásról visszatérő munkavállalói kezébe abban a tekintetben, hogy szabadabban dönthessenek arról, hány órában térnek vissza dolgozni, legalább annyiban, hogy négy- vagy (egy átlagos bölcsődei nyitvatartáshoz jobban igazodó) hatórás részmunkaidö közül választhassanak.

\subsection{Felmondási védelem}

A 2012 előtti szabályozáshoz képest az egyik legmarkánsabb negatív változás a felmondási védelem körét érinti. A dolgozó anyákat és a gyereküket egyedül nevelő apák már nem az abszolút hatályú felmondási tilalom alá esnek, hanem relatív védelemben részesülnek. ${ }^{39}$ Relatív védelem illeti meg azokat is, akik beteg gyereküket vagy hozzátartozójukat ápolják, illetve azokat, akik szülési vagy gyermekgondozási szabadságot nem vesznek igénybe. Azonban ez megfelelő aktív munkaerőpiaci intézkedések hiányában nem biztosít kellő védelmet a családfenntartók számára, az egzisztenciális félelem pedig növeli a munkavállalók munkahelyi kiszolgáltatottságát.

Mindenképpen pozitív változást hozott a 17/2014. (V. 30.) AB határozat, amely a terhes nőket megillető felmondási tilalom „aktiválásához” szükséges munkavállalói nyilatkozat megtételének időpontját érintette. ${ }^{40} \mathrm{Nem}$ ennyire egyértelmủ az erre adott jogalkotói válasz: a módosítást követően a munkáltató visszavonhatja a felmondást, amennyiben jogellenességet észlel. Egyfelöl ez a szabály nem fogalmaz meg egyértelmű kötelezettséget a munkáltatóval szemben, másfelöl a jogalkotó nem tisztázza azt sem, hogy a munkavállalónak meddig van lehetősége élni a bejelentés jogával. Kiterjesztő jogértelmezés szerint annak sincs akadálya, hogy a felmondási idő lejárta után is érvényesíthesse a munkavállaló a védelmet, ugyanakkor konkrét jogszabályi rendelkezés hiányában kétséges, hogy a munkáltató hajlandó-e visszavonni a felmondást, illetve nincsen relevanciája a felmondás visszavonási lehetőségének, ha a munkaviszony időközben megszünt.

A várandós és szülési szabadságon lévő nők védelmét szolgálja a 92/85/EGK irányelv, amely kimondja, hogy védelem illeti meg a munkavállalókat a terhességük kezdetétől a szülési szabadság végéig, az állapotukkal összefüggésbe nem hozott, a nemzeti jogszabályok, illetve gyakorlat által megengedett különleges esetektől el-

\footnotetext{
${ }^{37}$ Munka Törvénykönyve 61. § (3).

${ }^{38}$ Magyarországon a részmunkaidős foglalkoztatottak aránya fokozatosan csökken, míg 2012-ben a munkavállalók 6,7\%-a, 2017-ben már csak 4,3\%-a dolgozott részmunkaidőben. Ezzel szemben az uniós átlag 19\% körül van. KSH: A 15-64 éves népesség részmunkaidős foglalkoztatási aránya, Eurostat, OECD.

${ }^{39}$ Munka Törvénykönyve 66 . § (6).

40 17/2014. (V. 30.) AB határozat, ABH 2014, 393.
} 
tekintve. Illetve az irányelv rögzíti, hogy amennyiben a munkavállalót az említett időszak alatt elbocsátják, a munkáltató köteles az elbocsátás megfelelően megalapozott indokait írásban megadni. ${ }^{41}$ Ezzel szemben az Mt. 79 . § alapján a munkáltató a határozott idejü munkajogviszonyt azonnali hatályú felmondással indokolás nélkül megszüntetheti, ha tizenkét havi, vagy ha a határozott időből hátralévő idő egy évnél rövidebb, a hátralévő időre járó távolléti díjat fizet a munkavállalónak. Ilyen esetekben a távolléti díj fizetése egyfajta alternatívának tünhet az indokolás helyett, azonban súlyosan sérti a munkavállalók érdekeit, mivel indokolás hiányában nem tudják bíróság előtt megtámadni a felmondást abban az esetben sem, ha arra az állapotuk miatt került sor. ${ }^{42}$ Elméletileg lehetősége van a munkavállalónak arra, hogy ilyen esetben - hasonlóan a próbaidő alatt történő azonnali hatályú felmondás esetéhez - az egyenlő bánásmód megsértésére hivatkozva akár az Egyenlő Bánásmód Hatósághoz, akár a bírósághoz forduljon, de álláspontunk szerint ez aránytalan nehézséget okoz a munkahelyét elveszített nőnek ahhoz képest, amelyet az indokolási kötelezettség okozna a munkáltatónak. ${ }^{43}$

További hátrányt jelent a jogellenes megszüntetés jogkövetkezményei terén bekövetkezett változás. Amennyiben egy kisgyermekes szülő munkaviszonyát a munkáltató jogellenesen, de nem felmondási védelembe vagy a diszkrimináció tilalmába ütköző módon szüntette meg (például nem megfelelően indokolta a felmondást), úgy a munkavállaló nem kérheti a munkaviszonya helyreállítását. Ugyancsak nem jogosultak helyreállítást kérni azok a szülők, akik nem vettek vagy három évnél rövidebb ideig vettek igénybe gyermekgondozás céljából igénybe vehető fizetés nélküli szabadságot. Mivel a jogellenes felmondás jogkövetkezményeinek 2012-ben bevezetett új szabályai jelentősen limitálják a munkavállalónak megítélhető kártérítés mértékét, a csekély anyagi kompenzáció nem képes ellensúlyozni azokat a nehézségeket, amelyek egy új munkahely keresésével járnak például egy gyermekét egyedül nevelő szülő vagy egy olyan várandós nő számára, akinek jogellenesen azonnali hatályú felmondással szüntették meg a munkaviszonyát illetve egyáltalán nem ösztönző azon anyák számára, akik hamarabb kívánnak visszatérni a munka világába.

A jogosultságok és kötelezettségek homályban hagyása ezen a területen is a sérülékeny munkavállalók nagyobb fokú kiszolgáltatottságát eredményezik. Szükségesnek tartjuk a felmondásra vonatkozó szabályok újragondolását. Változtatásra szorul a felmondási védelemre vonatkozó szabály, ennek egyik oldala a megfelelő határidő megállapítása, a másik lényeges eleme pedig a munkáltatói kötelezettség egyértel-

${ }^{41}$ A Tanács 92/85/EGK irányelve (1992. október 19.) a várandós, a gyermekágyas vagy szoptató munkavállalók munkahelyi biztonságának és egészségvédelmének javítását ösztönző intézkedések bevezetéséröl, 10. cikk.

${ }^{42}$ Ahogyan arra az Alkotmánybíróság is rámutatott, indokolás hiányában nem várható, hogy a bíróság érdemben vizsgálja a felmentés jogszerűségét, az indokolási kötelezettség hiánya gyakorlatilag megszünteti a munkajogi védelmet és kiüresíti az Alkotmány 57. § (1) bekezdésében szabályozott alapvető jogot, a bírósághoz fordulás jogát. Lásd: 1068/B/2010. AB határozat $A B H$ 2011. 49.

${ }^{43}$ Lásd például az EBH/309/2018 határozatot a várandós nő védelméről a próbaidő alatti azonnali hatályú felmondással szemben; megjegyezendő ugyanakkor, hogy az Egyenlő Bánásmód Hatóság szankciórendszere - mint az idézett ügyben a munkáltatóval szemben kiszabott 500 ezer forintos bírság - nem jelent valódi védelmet a kérelmező számára, mivel a munkaviszony helyreállítására vagy kártérítési felelősség megállapítására csak a bíróság jogosult. 
müvé tétele lenne. A jogérvényesítés szempontjából fontos lenne, hogy a munkáltató köteles legyen minden esetben indokolni a felmondását, ha várandós nő jogviszonyát szünteti meg. Továbbá lényegesen kedvezőbb helyzetbe kerülnének a kisgyermekes szülök, ha a jogellenes megszüntetés jogkövetkezményei között a jogviszony helyreállítását is kérhetnék.

\subsection{Az apákra vonatkozó szabályok}

A Munka Törvénykönyve nagyon kevés rendelkezést tartalmaz az apákról. Egyrészt az apának gyermeke születése esetén, legkésőbb a születést követő második hónap végéig, öt, ikergyermekek születése esetén hét munkanap pótszabadság jár. Ennek a szabadságnak az igénylése sok szempontból korlátok közé esik, annak ellenére, hogy a munkavállaló kérésének megfelelő időpontban kell kiadni. Egyfelől vonatkoznak rá a szabadság kiadására vonatkozó szabályok, másfelöl, ha az apa a megadott időintervallumban nem tudja kivenni a pótszabadságot (például azért, mert keresőképtelen), úgy elveszíti a jogosultságát. ${ }^{44}$ Figyelemre méltó továbbá, hogy az apát felmondási védelem sem illeti meg a pótszabadság idejére.

Másrészt a gyermekét egyedül nevelő apa ${ }^{45}$ felmondási korlátozás alá esik a gyermek hároméves koráig, ha a munkavállaló a gyermek gondozása céljából fizetés nélküli szabadságot nem vesz igénybe. ${ }^{46}$

A munkaidő beosztásának szabályai között, a gyermeküket egyedül nevelő szülőkre vonatkozó szabályok kivételével, ${ }^{47}$ nem találunk olyan kedvezményt, amely a kisgyermekes apákat érintené. Ez nemcsak az apákra, de az anyákra is kihatással van, mivel közvetve érintik őket a nem megfelelő munkaidő-beosztásból, a munkaszerződéstől való eltérő foglalkoztatásból származó hátrányok. Abban az esetben például, ha a kisgyermekes apát más munkahelyen foglalkoztatják vagy éjszakai munkára osztják be, az anyára hárul a feladat, hogy a gyerekkel kapcsolatos feladatokat ellássa.

Nem találunk olyan szabályt sem, amely a kisgyermekes apát védené a munkáltatói felmondással szemben. Ez pedig, a fentebb kifejtettek alapján, azt jelenti, hogy az „egykeresős” családmodellekben hatalmas nyomás nehezedik a kenyérkereső apára, aki akár a családjával tölthető idő és energia rovására is meg akar felelni a munkáltatói elvárásoknak, hogy biztonságban tudhassa az állását.

\footnotetext{
${ }^{44}$ Az 1992. évi XXII. törvény 138/A. § (1) alapján az apát gyermeke születése esetén öt munkanap munkaidőkedvezmény illette meg, amelynek igénybevételi feltételei emiatt lényegesen kedvezőbbek voltak.

${ }^{45}$ Gyermekét egyedül neveli az apa, ha gyermekét saját háztartásában neveli és nőtlen, özvegy, elvált, házastársától külön él és nincs élettársa (Mt. 294. § (1) bekezdés i) pont).

${ }^{46}$ Ebben az esetben a munkáltató felmondással csak akkor szüntetheti meg a munkaviszonyt, ha a munkavállaló munkaviszonnyal kapcsolatos magatartásával indokolt felmondása az Mt. 78. § (1) bekezdésében meghatározott ok alapján is megállna, illetve a munkavállaló képességével vagy a munkáltató működésével összefüggő okból akkor szüntethető meg a jogviszony, ha a munkáltatónál nincs a munkavállaló által betöltött munkakörhöz szükséges képességnek, végzettségnek, gyakorlatnak megfelelö betöltetlen másik munkakör vagy a munkavállaló az e munkakörben való foglalkoztatásra irányuló ajánlatot elutasítja (Mt. 66. § (4)-(6)).

${ }^{47}$ Mt. 113. §.
} 
A munkáltató beosztással kapcsolatos döntésével szemben az apa legfeljebb a méltányos mérlegelés alapelvére számíthat. Viszont a bírói gyakorlat következetes abban, hogy ez az alapelv nem alkalmazható a munkaviszony-megszüntetés és létszámcsökkentés esetén, mivel a munkaviszony-megszüntetés bár egyoldalú intézkedés, egyértelműen nem a munkaviszony teljesítésére irányul. ${ }^{48}$

Annak ellenére, hogy a nyitott jogi normák útján történő szabályozás kívánatosnak tartott fejlődési irány a munkajogban, a magyar joggyakorlatban a méltányos mérlegelés bírói gyakorlata az Mt. hatályba lépése óta eltelt több mint öt év alatt sem épült ki. ${ }^{49} \mathrm{Az}$ alapelvi szintû szabályozás további nehézsége, hogy a munkavállaló nem tud gyorsan, az utasítás pillanatában hatékonyan hivatkozni rá, hiszen a végső szót a bíró mondja ki, ha a munkavállaló kifogásolja a munkáltató utasítását, és adott esetben megtagadja annak végrehajtását. ${ }^{50}$ Erre a problémára a konkrét szabály ellenére sem biztosított szélesebb körü védelmet a korábbi Mt. rendelkezése. ${ }^{51}$

A nemrég hatályba lépett uniós irányelv, amely a szülök és a gondozók munka és magánéleti egyensúlyáról szól, ${ }^{52}$ lehetőséget ad az apákra vonatkozó szabályozás felülvizsgálatára. Összhangban az irányelvvel mindenképpen szükségesnek tartanánk, hogy majd ne csak az apasági és a szülői szabadság idejére biztosítson a jogalkotó felmondási védelmet, ${ }^{53}$ hanem az Mt. 66. $§(6)$ bekezdésében foglalt védelmet terjessze ki az apákra is. Ezenkívül olyan garanciális elemek beiktatását is szükségesnek gondoljuk, amelyek a kedvezőtlen munkaidő-beosztással szemben védik a kisgyermekes apákat. ${ }^{54}$ Ilyen lehet például az Mt. 113. §-ában foglalt kedvezményszabályok alkalmazása azokra az apákra, akiknek háromévesnél fiatalabb gyermekük van.

\section{A kisgyermekes nők munkaerőpiaci visszatérését támogató intézkedések}

A kisgyermekes nők szülés utáni munkába állását, illetve a munkába való visszatérését számos intézkedés igyekszik elősegíteni. Az intézkedésekkel érintett területek és a juttatások fokozatosan nőnek, a szabályanyag ezzel párhuzamosan viszont

${ }^{48}$ Petrovics Zoltán: A biztonság árnyékában - A munkajogviszony megszüntetésével szembeni védelem alapkérdései. Doktori Értekezés, ELTE ÁJDI, 2016, 232.

${ }^{49}$ Kun Attila: A méltányos mérlegelés elve a magyar munkajogban: méltánytalanul mellőzve? Magyar Jog, 2017/12, 734-745.

50 Mt. 54. § (2).

${ }^{51}$ Lásd az 1992. évi Munka Törvénykönyve, 83/A. § (2) és 127. § (2) bekezdéseit, amely az átirányítás és a rendkívüli munkavégzés esetére tartalmaztak korlátot. Ezekben az esetekben az elrendelés nem járhatott a munkavállaló számára aránytalan sérelemmel. A bírói gyakorlat alapján a „rendeltetésszerű joggyakorlás” elvére hivatkozással érvényteleníthetők voltak az egyes munkáltatói utasítások, például külföldi kirendelés abban az esetben, ha a munkavállaló idős, beteg hozzátartozóját gondozza, lásd: EBH2009.1979.

52 Az Európai Parlament és a Tanács (EU) 2019/1158 irányelve (2019. június 20.) a szülők és a gondozók vonatkozásában a munka és a magánélet közötti egyensúlyról és a 2010/18/EU tanácsi irányelv hatályon kívül helyezéséröl, L-188/79, 2019.7.12.

11453 (EU) 2019/1158 irányelv 10. cikk.

54 (EU) 2019/1158 irányelv 9. cikk (1)-(2). 
egyre kevésbé áttekinthető, amely elsősorban a foglalkoztatók számára jelenthet nehézséget, mivel például az érvényesíthető adókedvezmények folyamatosan változnak. Ehelyütt részletesebben a „GYED extra” szabályaival foglalkozunk.

A GYED extra bevezetését mérföldkőnek tekintette a kormány a családtámogatások történetében. A GYED extrát az a szülő veheti igénybe, aki a gyermeket saját háztartásában neveli, ha biztosított, vagy a biztosítási jogviszonya a csecsemőgondozási díjra való jogosultság időtartama alatt szünt meg, és a gyermek születését megelőző két éven belül 365 napon át biztosított volt.

Az intézkedés négy, egyre szélesedő területet fed le. A nők munkaerőpiaci viszszatérést feltehetően leginkább segítő szabály, hogy a gyermekgondozási ellátások melletti munkavégzési korlátozások megszüntek a gyermek féléves kora után. Azaz a GYED, illetve a GYES folyósítása mellett is szabadon létesíthető munkaviszony, tehát nem köti a korábbi foglalkoztatóhoz a szülöt. A gyermekgondozási ellátások egyszerre több gyermek után is igénybe vehetök kistestvér születése esetén. Ez az ellátási forma bár több pénzhez juttatja a szülöket, egyben rendkívül pazarló is, hiszen a teljes állásban dolgozó szülő gyermeke egy államilag finanszírozott intézményben van napközben, azaz az állam egy olyan ellátást finanszíroz, amelyet a szülö nem nyújt. Emellett azok az ellátások, amelyeket a hátrányosabb helyzetü családok vehetnének igénybe, különösen a GYES, összege 2000 óta változatlan, reálértéken pedig a harmadát veszítette el. ${ }^{55}$

A gyermekgondozási díjra jogosultak köre 2014-ben a felsőoktatási intézmény hallgatóival egészült ki. Úgynevezett „diplomás GYED”-re lehetnek jogosultak azok, akik - többek között - felsőfokú tanulmányaik alatt vagy a tanulmányok megszünését követő 1 éven belül szülnek. A gyermekek a szülők korábbi életkorában való megszületése érdekében az anya vagy az apa is részesülhet két évig a diplomás GYED-ben. A támogatás lényege, hogy a felsőoktatásban részt vevő nő ne halassza el a gyermekvállalást azért, mert nincsen meg a magasabb összegű GYED-re való jogosultsága. Ugyanakkor azoknak a családoknak az ellátása gyengült, ahol alacsonyabb az iskolai végzettség a szülök és a gyermekek körében: a családi pótlék egyfelöl veszített az univerzális jellegéből azáltal, hogy iskoláztatási feltételhez kötötték, másfelöl sok család veszítette el a jogosultságát a tankötelezettség 18-ról 16 évre szállításával. ${ }^{56}$

A 2013-tól életbe lépő Munkahelyvédelmi Akció úgy kívánta megkönnyíteni a kisgyermekes anyák visszatérését a munkaerőpiacra, illetve a munkáltatókat érdekeltté tenni a női munkaerő megtartásában, hogy a kisgyermekes nők foglalkoztatása esetén a munkáltató járulékkedvezményt vehet igénybe. Továbbá 2014. január 1-től már differenciáltan kezeli a visszatérő szülőket a gyermekeik száma alapján, így a 3 és több gyermekesek esetében a munkáltatók által fizetett járulékkedvezmény 1-1 évvel kibövült.

\footnotetext{
55 SzIKRA Dorottya: Távolodás az európai szociális modelltől - a szegénység társadalompolitikája. Magyar Tudomány, 2018/6, 858-871.

${ }^{56}$ Becslések szerint 2010 és 2015 között kétszázezer gyerek hullott ki a rendszerböl, feltételezhetöen zömmel a rosszabb anyagi körülmények között lévő családokból. Lásd SzIKRA (2018) i. m., 868.
} 
A bőkezű támogatások ellenére a Statisztikai Hivatal felméréséből arra következtethetünk, hogy az intézkedés nem érte el a kívánt célt. A megkérdezettek $84 \%$-a nem tervezete, hogy a gyermekgondozási szabadság letelte előtt visszatér, és csak az 1,8\%-uk nyilatkozott úgy, hogy igénybe kívánja venni a GYED extrát és munkát vállal. A pozitív választ adó nők 16\%-a felsőfokú végzettséggel és relatíve magasabb jövedelemmel rendelkezik. Az alacsonyabb iskolai végzettségű és alacsonyabb jövedelmű nők számára arányaiban nagyobb költséget jelent a munkába járás. Az ő esetükben egy (feltehetően szintén alacsony jövetelemet jelentő) állás betöltése esetén nem térülnének meg a járulékos költségek. A megkérdezettek 14\%-a nyilatkozott úgy, hogy a munkába való visszatérése elviselhetetlen terhet róna a családra a rugalmatlan munkaidő-beosztás miatt. ${ }^{57}$

\section{5. Összefoglalás}

A kutatások azt mutatják, hogy a munkaerőpiacon tapasztalható növekvő verseny tovább szúkíti a munkavállalók jogait azzal, hogy a munkaadók nagyobb rugalmasságot követelhetnek a munkavállalóiktól, amely riasztóan hat a gyermekvállalásra, de különösen az első szülés idejére. Azok a nők, akik a karrierjük elején szülnek, számos nehézséggel szembesülnek, elsősorban munkahelyi bizonytalansággal és a munkavállalásukat nem támogató környezettel. Habár a kormány egyik oldalról növeli az anyáknak nyújtott pénzbeli támogatásokat, hogy ösztönözze a munkaerőpiacra való visszatérésüket, ezt másik oldalról nem követi a munkaerőpiaci szabályozások kedvező kialakítása, amely jobban igazodna a kisgyermekes szülők szükségleteihez. Ezenkívül a pénzbeli juttatások növekvő rendszere csak a középosztálybeli családoknak nyújt segítséget, míg az alacsony jövedelemmel rendelkező családok és nők szinte semmilyen támogatásban nem részesülnek. Mivel az egyéni alkupozíció általában alacsonyabb az alacsony fizetésü, alacsony képzettségü munkák esetében, növekszik a nők kiszolgáltatottsága és a társadalmi kirekesztés kockázata.

A hatályos munkajogi szabályozások nem teszik lehetővé, hogy a szülők általában, de a kisgyermekes nők különösen, a nem családos munkavállalókkal egyenlő értékű munkaerőként jelenjenek meg a munkaerőpiacon. A 2012-es munkajogi reform egyik kiemelt célkitüzése volt a munkaviszony rugalmasítása, azonban a szabályok nagyrészt a munkáltatók érdekeit veszik csupán figyelembe. A munkavállalói jogok és munkáltatói kötelezettségek homályban hagyása például a várandós nők felmondási védelmével vagy a méltányos mérlegelés alapelvével kapcsolatban tovább fokozza a családos munkavállalók kiszolgáltatottságát, így növelve az egyébként is létező egzisztenciális félelmüket.

Ahhoz, hogy a családpolitikai intézkedések elérjék a kívánt céljaikat, meg kell teremteni az összhangjukat a foglalkoztatáspolitikai eszközökkel. ${ }^{58}$ Különösen fontos lenne a Munka Törvénykönyvének átfogó reformja abból a szempontból, hogy ne

\footnotetext{
${ }^{57}$ A kisgyermeket nevelő nők és a munkaerőpiac, KSH, Statisztika Tükör, 2015/55.

58 GYARMATI Andrea: Changing values and measures in population policy, social policy and child protection in the Hungarian system of family benefits from 1989 to 2008. In: Scharle Ágota. (ed.): Manka goes to work. Pub-
} 
csak megfelelő rugalmasságot, hanem kellő szintủ biztonságot is adjon a családos munkavállalóknak. Ennek keretében a felmondással kapcsolatos szabályok konkretizálására, a munkaviszony jogellenes megszüntetése esetén a helyreállítás mint jogkövetkezmény választásának kiszélesítésére, az apákra is kiterjedő felmondási védelem megteremtésére, a család és a magánélet összeegyeztethetőségét nehezítő munkaidő-beosztással szembeni garanciák megteremtésére és a négyórás mellett a hatórás részmunkaidőre való jogosultság szabályba foglalására tettünk javaslatot.

Ezenfelül szükségesnek tartjuk a családpolitikai intézkedések felülvizsgálatát abból a szempontból, hogy az alacsonyabb jövedelmü, netán munka nélküli szülöknek is megfelelő ellátást biztosítson. Ennek eszköze lehetne akár a rövidebb biztosítási idő feltételül szabása, a közmunkaprogramban történő részvétel beszámítása, illetve az alanyi jogon járó juttatások, elsősorban a GYES és a családi pótlék összegének az emelése.

\section{Abstract}

Labour market situation of young mothers highly depends on the convergence of family and employment policies. Since 2010 there have been important changes in the Hungarian policies in order to stimulate fertility and to enhance female employment rate. In our research we combined legal and sociological methodologies to analyse the effect of these policies. We argue that Hungarian policy has been in a serious uphill struggle to find a balance between two contradicting principles: providing sufficient family allowances and maintaining labour market flexibility by weak protection of employees. This dichotomy of principles has led to an unsustainable employment policy and make women more vulnerable on the labour market. We suggest that the differences would be reconciled through labour reforms, measures concerning working time arrangements, part time work and protection against dismissal have to be revisited along with protection of fathers with young children.

lic childcare in the Visegrad countries. 1989-2009. Budapest Institute for Policy Analysis, Budapest, 2010. 